UDC 623.1/.7:007.52 (477)

\title{
INFLUENCE OF AIR SHOCK WAVE ON SHELTER
}

\author{
V.I. Kotsyuruba, \\ Doctor of Technical Science, Professor, Honored Inventor of Ukraine \\ I.P. Datsenko, \\ Candidate of Technical Sciences \\ V.O. Dachkovsky, \\ Candidate of Technical Science \\ R.M. Cherevko, \\ V.M. Polyulyak, \\ O.A. Ivashchuk, \\ I.I. Furman, \\ Doctor of Historical Science, Docent \\ National Defense University of Ukraine named after Ivan Chernyakhovsky \\ 28, Povitroflotskiy avenu, Kyiv, Ukraine
}

DOI: $10.32347 / 2410-2547.2020 .105 .133-144$

In modern conditions, sheltering people in protective structures, as a way of protection from dangers, in combination with evacuation from the affected areas (pollution) and the use of personal protective equipment, increases the reliability of public protection. In conditions when evacuation measures from cities can be complicated in a short time, protection of the population in shelters becomes the only possible and effective. Therefore, an important task is to study the impact of loads caused by the explosion of various munitions, substantiate recommendations for improving the protective properties of the shelter and the choice of their location.

The most common issues are considered in the article that arise during the arrangement of shelter in buildings and outside them. Based on experimental studies, Taylor's formula and the system of non-stationary Navier-Stokes equations for gas, it's conducted an analysis of the influence of external and internal factors on the possible nature of the dynamic load from the shock wave on buildings, structures and structural elements in which shelters are located.

The results of studies of the parameters of dynamic loads showed that if the storage facilities are located in the basements of buildings, their stability is characterized by three parameters: maximum pressure, time to increase the load to maximum and effective time. The parameters of the loads and the law of their change over the time depend on the location of the structure relative to the surface of the earth and the building, the force of the explosion and the distance to the center of the explosion.

Key words: dynamic load, shock wave, breakthrough wave, shock wave pressure, load rise time, load action time, technical basement, separate shelters.

Introduction. In recent years, issues of civil protection have come to the fore and become one of the most actual problems of the modern world. This applies to all countries in the world, regardless of economic and political status: the ever-increasing threat of terrorist acts, man-made and natural disasters, the modern conditions of urbanization of society and the high probability of military conflicts, such as hostilities in eastern Ukraine

Kotsiuruba V.I., Datsenko I.P., Dachkovsky V.O., Cherevko R.M., Polyulyak V.M, Ivashchuk O.A., Furman I.I. 
supported by the Russian Federation. During armed conflicts, the most part of hostilities takes place near or directly in settlements, and settlements are shelled by illegal armed groups, necessitating the protection of not only military formations but also civilians. As a result, there is a need to study and determine the optimal location of shelter equipment and materials for their equipment.

The analysis of works devoted to the study of the action of dynamic loads and properties of structures used in the construction of shelters indicates the aggravation of the need to study the impact of loads caused by explosions of different nature [1-5].

Currently, one of the main materials for construction is reinforced concrete, which is an integral part of most modern buildings. In accordance to the building codes and rules, the construction of shelters are calculated on the totality of all loads that may affect the structure [6-9].

The above-indicated causes the necessity of the more deeper study of the impact of the results of the explosion process, the calculation of the stability of shelter structures and the choice of their locations. Therefore, the aim of the article is to research the effect of dynamic loads from the shock wave on the shelter.

The main material of the article. Dynamic loads from the shock wave in practical calculations are reduced to equivalent static loads that cause the same deformations in the structure as dynamic.

If we take into account the displacement of the structure and the deformation of the structural elements, the equivalent loads are determined in two stages. At the first stage, the dynamic loads on the structural elements of the structure are determined, and at the second stage, the static loads are determined directly. Dynamic loads caused by an explosion are usually characterized by three parameters: maximum pressure $P_{\max }$, the time of increase of the load to the maximum $t_{\text {nar }}$ and the time of action $\tau_{\epsilon}$. The parameters of the load and the law of its change in time depend on the location of the structure relative to the surface of the earth and the building, the force of the explosion and the distance to the center of the explosion [7].

In the practice of design, different storage options can be reduced to four calculation cases:

1) shelters are placed on the ground floor of the building;

2) shelters are erected in the basement or basement of the building;

3) shelters are placed under the technical basement (TB) (technical underground);

4) shelters are located separately, completely or partially sunk into the ground.

The results of the study on 3 and 4 options are revealed in the article. In particular, the influence of dynamic loads from the shock wave on the elements of reinforced concrete structures, the study of which was carried out using experimental data, the finite element method, Taylor's formula, the 
system of nonstationary Navier-Stokes equations for gas and their approximation [10-12].

1. Determination of dynamic loads on the shelter are placed under the technical basement. In the case when the shelter is placed under the TB, when exposed to an air shock wave on the building, the wave first flows into the premises of the first floor, and then into the premises of the TB through the holes formed by the destruction of the floor (Fig. 1).

When determining the characteristics of the wave flowing into the $T B$, the following prerequisites are accepted: the time of pressure build-up in all rooms of the first floor and the estimated margin of safety are not taken into account; floor slabs under load work for the scheme of the hinged beam, the destruction of which occurs in the hinge of plasticity; the wave flows through the responses, which are simultaneously created by rotating the convenient structures relative to the supports; the walls of the TB are not destroyed.

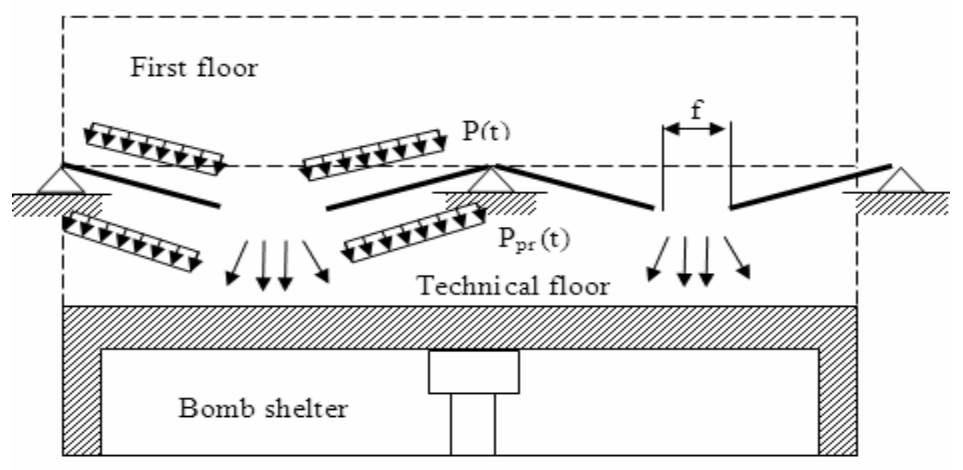

Fig. 1. Calculation scheme for determining the parameters of the penetration wave in the technical floor

The destruction of the NB floor slabs occurs under the action of load. After the destruction of the plastic hinge on the inside of the floor, back pressure begins to act, which is taken equal to the pressure of the breakthrough wave $\Delta P_{F}=[\varphi(t), t]$. After the failure of the hinge, the load depends on the movement of the floor halves, the size of the gap and the process of flow of the wave into a closed volume, that's there is a relationship. The solution of the equations of motion of the floor slabs is carried out together with the equations of gas dynamics on the flow of the wave into closed volumes.

The maximum pressure in the flow wave is taken equal to the pressure at the moment of equalization of pressures before the break and inside the TB. The results of calculations of corresponding types of overlap (Table 2) are shown in Table 1. 
Table 1

The parameters of the flow wave in the TB at the pressure on their overlap, $10^{5} \mathrm{~Pa}$

\begin{tabular}{|c|c|c|c|c|}
\hline \multirow{2}{*}{$\begin{array}{c}\text { Type of } \\
\text { overlapping }\end{array}$} & \multicolumn{2}{|c|}{0,5} & \multicolumn{2}{|c|}{3} \\
\cline { 2 - 5 } & $\Delta P_{z a t}^{\max }, 10^{5} \mathrm{~Pa}$ & $t_{\text {nar }}, \mathrm{m} / \mathrm{sec}$ & $\Delta P_{\text {zat }}^{\max }, 10^{5} \mathrm{~Pa}$ & $t_{\text {nar }}, \mathrm{m} / \mathrm{sec}$ \\
\hline 1 & 0,43 & 124 & 2,36 & 57 \\
2 & 0,43 & 137 & 2,31 & 64 \\
3 & 0,44 & 129 & 2,39 & 58 \\
4 & 0,48 & 143 & 2,33 & 65 \\
5 & 0,44 & 130 & 2,39 & 63 \\
6 & 0,43 & 146 & 2,32 & 70 \\
7 & 0,42 & 150 & 2,25 & 70 \\
8 & 0,42 & 142 & 2,30 & 70 \\
\hline
\end{tabular}

Table 2

Characteristics of overlapping by types

\begin{tabular}{|c|c|c|}
\hline $\begin{array}{c}\text { Type of } \\
\text { overlapping }\end{array}$ & $\begin{array}{l}\text { Weight per unit } \\
\text { area, } \mathrm{kg} / \mathrm{m} 2\end{array}$ & Characteristics of overlapping \\
\hline 1 & 240 & $\begin{array}{l}\text { 1. Overlapping from plates of continuous } \\
\text { section. Material - heavy concrete. } \\
\text { 2. Overlapping from monolithic reinforced } \\
\text { concrete }\end{array}$ \\
\hline 2 & 330 & $\begin{array}{l}\text { 1. Overlapping from plates of continuous } \\
\text { section. Material - heavy concrete. } \\
\text { 2. Overlapping from monolithic reinforced } \\
\text { concrete }\end{array}$ \\
\hline 3 & 260 & Precast reinforced concrete, hollow decking \\
\hline 4 & 350 & $\begin{array}{l}\text { Precast reinforced concrete, hollow decking. } \\
\text { Floors: } 1 \text { - light concrete } 50 \mathrm{~mm} \text {, cement-sand } \\
\text { screed } 25 \mathrm{~mm} \text {, cold mastic } 1 \mathrm{~mm} \text {, linoleum } 4 \\
\mathrm{~mm} ; 2 \text { - plank floor on logs. }\end{array}$ \\
\hline 5 & 260 & Precast concrete, ribbed slab. \\
\hline 6 & 350 & $\begin{array}{l}\text { Precast concrete, ribbed slab, linoleum floor, } \\
90 \mathrm{~kg} / \mathrm{m} 2 \text {. }\end{array}$ \\
\hline 7 & 420 & $\begin{array}{l}\text { 1. Overlapping from plates of continuous } \\
\text { section. Material - heavy concrete. } \\
\text { 2. Overlapping from monolithic reinforced } \\
\text { concrete. The weight of the floor per unit area } \\
\text { is } 90 \mathrm{~kg} / \mathrm{m} 2 \text {. }\end{array}$ \\
\hline 8 & 330 & $\begin{array}{l}\text { 1. Overlapping from plates of continuous } \\
\text { section. Material - heavy concrete. } \\
\text { 2. Overlapping from monolithic reinforced } \\
\text { concrete. The weight of the floor per unit area } \\
\text { is } 90 \mathrm{~kg} / \mathrm{m} 2 \text {. }\end{array}$ \\
\hline
\end{tabular}


Calculations have shown that the destruction of the floor of the TB, made of the most common in the practice of building slabs, reduces the pressure of the inflow wave by $14 \%$ at a pressure of $0,5 \cdot 10^{5} \mathrm{~Pa}$ and by $22 \%$ at a pressure of $3 \cdot 10^{5} \mathrm{~Pa}$. The time of increase of pressure during the destruction of these plates makes: at pressure $0.5 \cdot 10^{5} \mathrm{~Pa}-$ $130 \mathrm{~ms}$; at a pressure of $3 \cdot 10^{5} \mathrm{~Pa}-60 \mathrm{~ms}$.

The dependence of the time of increase $t_{\text {nar }}$ of the penetration wave and the coefficient of the shielding effect $C_{n}$ from the pressure $P_{F} \quad$ at the destruction of the floor of different densities is shown in Fig. 2.

Analysis of the established dependences (Fig. 2) showed that the dynamic load on the floors of shelters located under the TB, as well as on the walls of shelters adjacent to the basement, not protected from shock waves, gradually increases to a maximum, which is determined by the formula:

$$
P_{\max }=\Delta P_{F} C_{c p} C_{p},
$$

where $C_{p}$ - coefficient that takes into account the shielding effect of the overlap, taken according to the graphs (Fig. 2); $C_{c p}$ - the coefficient taking into account the shielding effect of the enclosing structures of shelters, which is accepted for buildings with a capacity of less than $10 \%$ in accordance with Table 3 , and for buildings with a capacity of $10 \%$ or more is equal to 1 .

2. Determination of dynamic loads on separately located shelters. The presence of a soil layer above the floor of separately located storage facilities leads to the fact that the structure is not affected by an air shock wave, but by a compression wave in the soil. The dynamic load on the floor is determined taking into account the reflection of the compression wave from the structure, which is displaced on the ground. The unloading wave, propagating from the free surface, is added to the compression wave, which reduces the load on the 
floor. As a result, the effect of the reflection pressure will be short-lived. If the thickness $\mathrm{h}$ of the soil layer above the floor is less than $1 \mathrm{~m}$, the effect of reflection on the bearing capacity of structural elements is insignificant and can be neglected.

Table 3

The value of the coefficient $c_{c p}$

\begin{tabular}{|c|c|c|}
\hline Characteristics of wall materials & Wall thickness, cm & Coefficient $c_{c p}$ \\
\hline $\begin{array}{c}\text { Panels of lightweight concrete with } \\
\text { density }\end{array}$ & 10 & 0,95 \\
$p=700-1200 \mathrm{~kg} / \mathrm{m}^{3}$ & $20-30$ & 0,90 \\
\hline $\begin{array}{c}\text { Brick masonry of ordinary brick, } \\
p=1800 \mathrm{~kg} / \mathrm{m}^{3}\end{array}$ & $\begin{array}{c}25 ; 38 \\
64\end{array}$ & 0,90 \\
\hline $\begin{array}{c}\text { Lightweight concrete blocks } \\
p=700-1200 \mathrm{~kg} / \mathrm{m}^{3}\end{array}$ & $40-50$ & 0,85 \\
\hline
\end{tabular}

The dynamic load on the solid slabs of the foundation and walls at $h \leq 1 \mathrm{~m}$ is determined in the same way as for shelters built into the building with a capacity of more than $50 \%$. However, when calculating the loads on the floor and the foundation at $1 \mathrm{~m}$ take into account the effect of reflection of the compression wave. The equation of motion of the shelter is written in the form:

$$
M u^{\prime \prime}=\left[\sigma_{m} f(t) k_{o t r}^{*}-A_{p} u^{\prime}\right] F_{p}-A_{F} u^{\prime} F_{F},
$$

where $M, F_{p}, F_{F}$ - the mass of the structure, the area of its floor and foundation; $\sigma_{m}$ - maximum of stress in the soil at the level of the floor; $k_{o t r}^{*}$ - reflection coefficient from a solid obstacle; $A_{p}, A_{F}$ - acoustic resistance of loose soil and base; $u^{\prime}$ - moving storage with specific weight $m ; f(t)-$ load function.

The expression $A_{p} u^{\prime} F_{p}$ takes into account the reduction of load due to the displacement of the structure.

Equation (2) at $m=\frac{M}{F_{p}}, P_{\max }^{n}=\sigma_{m} k_{o t r}^{*}$, take to the following form:

$$
m u^{\prime \prime}=P_{\max }^{n} f(t)-\bar{A}_{F} u^{\prime} .
$$

where $P_{\max }^{n}$ is the maximum pressure on the floor; $\bar{A}_{F}$ is acoustic resistance of compacted soil.

For practical calculations the load on the floor is determined by the formulas:

$$
P_{\max }^{n}=\Delta P_{F} k_{z a t} k_{o t r}
$$




$$
\begin{gathered}
k_{\text {otr }}=k_{\text {otr }}^{*}\left[1-\frac{1}{k_{2}}+\frac{1}{k_{2}}\left(1-\exp \left(-\frac{1}{k_{1}}\right)\right)\right] \\
k_{1}=\frac{m}{A_{p} k_{2} t_{\text {nar }}}, \quad k_{2}=1+a_{1} A_{F} A_{p}, \quad a_{1}=\frac{F_{F}}{F_{p}},
\end{gathered}
$$

where $k_{z a t}$ is the attenuation coefficient of the wave; $k_{\text {otr }}^{*}$ determined by the formula:

$$
k_{o t r}^{*}=2-\left(1-\frac{a_{1}}{a_{0}}\right) \frac{\sigma_{s}}{\sigma_{m}}(X),
$$

If in the calculations $k_{\text {otr }}$ is less than one, then $k_{\text {otr }}=1$ is accepted.

The load on the foundation (at $a_{1}=1, R=\left(A_{F}+\frac{A_{p}}{m}\right)$ ) is determined by the formula

$$
P_{\max }^{n}=\Delta P_{F} k_{z a t} k_{F}
$$

where $k_{F}$ is the strength factor of the foundation material.

For built-in storage, the time of action of the load on the floor, including the increase to the maximum and decrease to zero, is taken equal to the effective time of the shock wave $\tau_{e}$. For separately located shelters with a scattering of more than $1 \mathrm{~m}$, the time $\tau_{e}$ is equal only to the time of reduction of the load on the floor.

3. Determination of dynamic loads on the elements of the entrances to the shelter. Loads on the elements of the entrances (walls, protective and airtight doors, etc.) mainly depend on their design solutions, air shock wave pressure and shielding effect of enclosing structures.

The calculation of dynamic loads is performed according to the formula

$$
P_{\max }^{B}=\Delta P_{F} k_{B},
$$

in which the value of the coefficient $k_{B}$ is taken from Table 4. Data $k_{B}$ (Table 4) are obtained by solving problems about the interaction of shock waves with the structures of the entrance and the propagation of waves inside buildings, taking into account their destruction.

Formula (9) determines the maximum value of the dynamic load on the areas of the outer walls of the shelter at the entrances and on the first (outer) protective or protective-airtight doors. The values $k_{B}$ given in Table 4 take into account almost all calculated cases.

It is established that if the entrances are located in unprotected basements, then take into account the consumption energy of the wave to destroy their floors. In this case, the coefficient $k_{B}$ is taken equal to the value $C_{p}$ according to the schedule (Fig. 2). The coefficient $k_{B}$ for all types of entrances located in buildings with a capacity of less than $10 \%$, should be multiplied by a 
factor $C_{c p}$ that takes into account the shielding effect of the building (Table 3).

The temporal characteristics of the laws of change of the input load are determined by the same dependencies that are used in determining similar values for the enclosing structures of storage.

The rise time $t_{\text {nar }}$ for the inputs in Table 4 is determined by the schedule (Fig. 2).

Table 4

The value of the coefficient $k_{B}$ depending on the type of entrance to the shelter

\begin{tabular}{|c|c|c|c|c|c|}
\hline \multirow{2}{*}{ 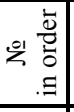 } & \multirow{2}{*}{\multicolumn{2}{|c|}{ Entrance }} & \multicolumn{3}{|c|}{$k_{B}$ at $P_{F}, 10^{5}$} \\
\hline & & & 1 & 2 & 3 \\
\hline 1 & \multicolumn{2}{|c|}{$\begin{array}{l}\text { From basements, not protected from shock } \\
\text { waves }\end{array}$} & 0,8 & 0,8 & 0,8 \\
\hline 2 & \multicolumn{2}{|c|}{ Through with a covered area against the entrance } & 1 & 1,1 & 1,2 \\
\hline \multirow{2}{*}{3} & \multirow{2}{*}{$\begin{array}{l}\text { From the premises of the } \\
\text { first floor with the area of } \\
\text { holes } 10-50 \%\end{array}$} & $\begin{array}{l}\text { a) below ground } \\
\text { level }\end{array}$ & 1 & 1 & 1 \\
\hline & & $\begin{array}{l}\text { b) above ground } \\
\text { level }\end{array}$ & 1,7 & 1,5 & 1,3 \\
\hline \multirow{2}{*}{4} & \multirow{2}{*}{$\begin{array}{l}\text { From stairwells with an } \\
\text { area of holes } 10-50 \% \text { at } \\
\text { the entrance to the } \\
\text { stairwell from the street }\end{array}$} & $\begin{array}{l}\text { a) below ground } \\
\text { level }\end{array}$ & \multirow{2}{*}{2,5} & \multirow{2}{*}{2,2} & \\
\hline & & $\begin{array}{l}\text { b) above ground } \\
\text { level }\end{array}$ & & & \\
\hline \multirow{2}{*}{5} & \multirow{2}{*}{$\begin{array}{l}\text { From the premises of the } \\
\text { first floor and stairwells } \\
\text { with an area of holes }> \\
60 \%\end{array}$} & $\begin{array}{l}\text { a) below ground } \\
\text { level }\end{array}$ & 2,7 & 2,5 & 2,2 \\
\hline & & $\begin{array}{l}\text { b) above ground } \\
\text { level }\end{array}$ & 3 & 2,7 & 2,3 \\
\hline 6 & \multicolumn{2}{|c|}{$\begin{array}{l}\text { Dead end without an area or with a light } \\
\text { (collapsible) pavilion }\end{array}$} & 2,7 & 2,5 & 2,2 \\
\hline 7 & \multicolumn{2}{|c|}{$\begin{array}{l}\text { Those that rise above the surface in the walls, as } \\
\text { well as the entrance from the apron }\end{array}$} & 3 & 2,7 & 2,3 \\
\hline
\end{tabular}

Dynamic loads on the inner walls, floor, ceilings and the second protective and airtight door of the vestibule-gateway are determined from the condition of possible flow of the shock wave through the open first protective-airtight door at the time of filling the vestibule-gateway. In this case, the dynamic load is approximately equal to the dynamic load on the outer walls of the shelter at the location of the entrance, multiplied by a factor of 0.8 .

The dynamic load on the outer walls of the shelter at the location of the first protective and airtight door is determined by Table 4 . The load from the 
inflow wave is taken linearly increasing to a maximum over time $t_{\text {nar }}$ with a subsequent decline to zero over time $t_{\text {nar }}=\tau_{e}-t_{\text {nar }}$.

It is proposed to determine the dynamic load on the inner walls of the vestibules and airtight doors under the conditions of the shock wave flow through possible leaks along the perimeter of the external door to the door frame. Such leaks can be due to hidden defects when installing embedded parts and elements of external doors.

At $\Delta P_{F}=0,2 \ldots 0,3 \mathrm{MPa}$ dynamic loading on the specified designs is accepted equal $0,025 \mathrm{MPa}$, and at $\Delta P_{F}=0,1-0,015 \mathrm{MPa}$.

Dynamic loads from the shock wave of leakage on the structure of the emergency exit (walls, ceilings and floor), designed in the form of a protected head with a mine and tunnel, as well as on the part of the wall at the junction of the exit are taken equal to the pressure $\Delta P_{F}$ multiplied by 1.6. It is also established that if the emergency exit is designed in the form of an inclined descent and a tunnel, the dynamic loads on its structural elements are taken equal to the pressure $\Delta P_{F}$ multiplied by the factor $k_{B}$.

These dynamic loads on the structures of the inputs and outputs are given for internal loads. Along with this load, the enclosing structures will experience external loads. These loads are determined in the same way as for coverings, walls and foundations of shelters.

Conclusion. Thus, the results of studies of the parameters of dynamic loads showed that at the location of storage facilities in the basements of buildings, their stability is characterized by three parameters: maximum pressure $R_{\max }$, time to increase $t_{\text {nar }}$ the load to maximum and effective action time $\tau_{e}$. The parameters of the loads and the law of their change in time depend on the location of the structure relative to the surface of the earth and the building, the force of the explosion and the distance to the center of the explosion.

Calculations have shown that the destruction of the floor of the TB, made of the most common in the practice of building slabs, reduces the pressure of the inflow wave by $14 \%$ at a pressure of $0,5 \cdot 10^{5} \mathrm{~Pa}$ and by $22 \%$ at a pressure of $3 \cdot 10^{5} \mathrm{~Pa}$. The time of increase of pressure at destruction of plates makes: at pressure $0,5 \cdot 10^{5} \mathrm{~Pa}-130 \mathrm{~m} / \mathrm{sec}$; at a pressure of $3 \cdot 10^{5} \mathrm{~Pa}-60 \mathrm{~m} / \mathrm{sec}$.

It is established that due to the dynamic loads of separately located shelters, the presence of a soil layer over the floor of separately located storage facilities leads to the fact that the structure is not affected by an air shock wave, but a compression wave in the soil.

For built-in storage, the time of action of the load on the floor, including the increase to the maximum and decrease to zero, is taken equal to the effective time of the shock wave $\tau_{e}$. For separately located shelters with scattering of more than $1 \mathrm{~m}$, the time $\tau_{e}$ is equal only to the time of load drop on the layer of scattering.

Calculations of dynamic loads on the elements of the entrances to the shelter have showed that their dependence on the inflow wave is linearly increasing to a 
maximum over time $t_{\text {nar }}$ with a subsequent decline to zero over time $t_{\text {nar }}=\tau_{e}-t_{\text {nar }}$. At $\Delta P_{F}=0,2-0,3 \mathrm{MPa}$ dynamic loading on the specified designs is accepted equal $0,025 \mathrm{MPa}$, and at $\Delta P_{F}=0,1 \mathrm{Mpa}-0,015 \mathrm{MPa}$.

As a direction of further researches is to establish the characteristics of the resistance of building elements to the dynamic impact of fragmentary elements.

\section{REFERENCES}

1. Mykhaylovska O.V. Zakriplennya stinok zakhysnykh sporud iz zastosuvannyam gruntotsementnykh elementiv (Fixing the walls of protective structures with the use of soilcementing elements)/ O.V. Mykhaylovska, O.B.Oleksiyenko // Visnyk Odeskoyi derzhavnoyi akademiyi budivnytstva ta arkhitektury, 2019. - № 75. - S. 44-52. (in Ukrainian)

2. Birbrayer A.N. Raschet konstruktsii na seysmostoykost (Structural analysis for seismic resistance)/ A.N. Birbrayer. - S.-Pb.: Nauka, 1998. - 255 s. (in Ukrainian)

3. Remez N.S. Dynamichna vzayemodiya hruntovykh osnov ta budivel pid chas diyi seysmovybukhovoho navantazhennya (Dynamic interaction of soil foundations and buildings during seismic and explosive loads) / N.S. Remez, I.A. Ivanova // Visnyk NTUU «KPI». 2015 r. - №29. - S. 24-30. (in Ukrainian)

4. Mkrtychev O.V. Raschet konstruktsiy zhelezobetonnogo zdaniya na vzryvnyye nagruzki v nelineynoy dinamicheskoy postanovke (Analysis of structures of a reinforced concrete building for explosive loads in a nonlinear dynamic setting) / O.V. Mkrtychev, V.B. Dorozhinskiy, O.V. Lazarev // Vestnik MGSU. - 2011. - №4. - S. 243-247. (in Russian)

5. Nabiullin M. I. Matematicheskaya model rascheta amplitudy izbytochnogo davleniya na fronte vozdushnoy udarnoy volny (Mathematical model for calculating the amplitude of excess pressure at the front of an air shock wave)/ M. I. Nabiullin, A. V. Guseva, D. YU. Verin, S. A. Vilokhin // Vestnik tekhnologicheskogo universiteta. 2017. T.20, №3 - S. 141144. (in Russian)

6. Tuzikov S.A. Analiz vymoh do zakhysnykh sporud tsyvilnoho zakhystu i metodolohichni pidkhody do yikh klasyfikatsiyi (Analysis of requirements for protective structures of civil defense and methodological approaches to their classification) / S.A. Tuzikov, S.O. Kovzhoha, YE.V. Karmannyy, A.F. Lazutskyy, A.V. Pysaryev // Zbirnyk naukovykh prats KHUPS. - 2013. - №1(34). - S. 186-189. (in Ukrainian)

7. Vasylchenko O.V. Budivelni konstruktsiyi ta yikh povedinka $\mathrm{v}$ umovakh nadzvychaynykh sytuatsiy: Navchalnyy posibnyk (Building structures and their behavior in emergency situations: A textbook) / O.V. Vasylchenko, YU.V. Kvitkovskyy, O.V. Myrhorod, O.A. Stelmakh. - Kharkiv: KHNADU, 2015. - 488s. (in Ukrainian)

8. Kobylkin I.F. Udarnyye i detonatsionnyye volny: Metody issledovaniya (Shock and Detonation Waves: Research Methods) / [I.F. Kobylkin, V.V. Selivanov, V.S. Solov'yev, N.N. Sysoyev].--M.: Fizmatlit, 2004. - 375s. (in Russian)

9. Kvitkovskyy Yu.V. Vyznachennya parametriv udarnoyi khvyli, shcho utvoryuyetsya pid chas vybukhu hazopovitryanoyi sumishi (Determination of the parameters of the shock wave formed during the explosion of the gas-air mixture) / Kvitkovskyy YU.V, Prokhach E.YU.// Zbirka naukovykh prats UTSZU. - №4, 2006. - S.120-124. (in Ukrainian)

10. Ovcharenko V.A. Osnovy metodu kintsevykh elementiv i yoho zastosuvannya v inzhenernykh rozrakhunkakh: nachalnyy posibnyk. (Fundamentals of the finite element method and its application in engineering calculations: a textbook)/ Ovcharenko V.A., Podlyesnyy S.V., Zinchenko S.M. - Kramatorsk: DDMA, 2008. - 380 s. (in Ukrainian)

11. Ivanova S.V. Formula Teylora i yeye prilozheniya $\mathrm{k}$ vychesleniyu predelov funktsiy: Uchebno-metodicheskoye posobiye (Taylor's formula and its application to calculating the limits of functions: Educational-methodical manual). - M.: MFTI, 2011. - 66 s. (in Russian)

12. Kalion V.A. Obchyslyuvalna hidromekhanika. Rivnyannya Navye-Stoksa: navch. posib. (Computational hydromechanics. Navier-Stokes equation: textbook.)/ V.A. Kalion. - K.: VPTS “ Kyyiv $\square$ kyy universytet”, 2016. - 221 s. (in Ukrainian) 
Кочюруба В.І., Дащенко І.П., Дачковський В.О., Черевко Р.М., Полюляк В.М., Іващук О.А., Фурман I.I.

\section{ВПЛИВ ПОВІТРЯНОЇ УДАРНОЇ ХВИЛІ НА УКРИТТЯ}

У протистоянні народу України агресивній політиці Російської Федерації $є$ актуальним питання вивчення досвіду бойових дійна сході нашої держави. Аналіз втрат, яких зазнали Збройні Сили України та мирне населення, за час ведення операції Об'єднаних сил (антитерористичної операції) на території Донецької та Луганської областей чітко вказують на необхідність вивчення питання впливу навантажень, викликаних вибухом різних за спорядженням боєприпасів, обгрунтування рекомендацій щодо підвищення захисних властивостей укрить та вибору місць їх розташування.

Конструкції таких споруд розраховують на особливі сполучення навантажень, що складаються 3 постійних, тимчасових, тривалих навантажень і навантажень, створюваних ударною хвилею.

В статті розглянуто найбільш поширені питання, що виникають на етапі улаштування укрить в будівлях та поза ними. На основі експериментальних досліджень, формули Тейлора та системи нестаціонарних рівнянь Нав'є-Стокса для газу проведено аналіз впливу зовнішніх та внутрішніх факторів на можливий характер динамічного навантаження від ударної хвилі на будівлі споруди та елементи конструкцій, у яких розташовуються укриття.

Метою статті $€$ дослідження впливу динамічних навантажень від ударної хвилі на укриття які розміщені під технічним підвальним приміщенням, що окремо розташовані та елементи входів в укриття.

Результати досліджень параметрів динамічних навантажень показали, що при розташуванні сховищ у підвальних приміщеннях будівель їх стійкість характеризується трьома параметрами: максимальним тиском, часом наростання навантаження до максимуму і ефективним часом дії. Параметри навантажень i закон їх зміни в часі залежать від розміщення споруди відносно поверхні землі і будівлі, сили вибуху і відстані до центру вибуху.

Ключові слова: динамічне навантаження, ударна хвиля, хвиля прориву, тиск ударної хвилі, час наростання навантаження, час дії навантаження, технічне підвальне приміщення, окремо розташовані укриття.

\section{УДК 623.1/.7:007.52 (477)}

Кочюруба В.І., Даценко І.П., Дачковський В.О., Черевко Р.М., Полюляк В.М., Іващук О.А., Фурман I.I. Вплив повітряної ударної хвилі на укриття // Опір матеріалів і теорія споруд: наук.-тех. збірн. - К.: КНУБА, 2020. - Вип. 105. - С. 133-144.

Розглянуто питання, що виникають на етапі улаштування укрить в будівлях та поза ними. На основі експериментальних досліджень, формули Тейлора та системи нестаціонарних рівнянь Нав'є-Стокса для газу проведено аналіз впливу зовнішніх та внутрішніх факторів на можливий характер динамічного навантаження від ударної хвилі на будівлі споруди та елементи конструкиій, у яких розташовуються укриття.

Табл. 4. Іл. 2. Бібліограф. 12 назв.

UDC 623.1/.7:007.52 (477)

Kotsiuruba V.I., Datsenko I.P., DachkovskyV.O., Cherevko R.M., Polyulyak V.M, Ivashchuk O.A., Furman I.I. Influence of air shock wave on shelter // Strength of Materials and Theory of Structures: Scientific-and-technical collected articles - Kyiv: KNUBA, 2020. - Issue 105. - P. 133-144.

The most common issues are considered in the article that arise during the arrangement of shelter in buildings and outside them. Based on experimental studies, Taylor's formula and the system of non-stationary Navier-Stokes equations for gas, it's conducted an analysis of the influence of external and internal factors on the possible nature of the dynamic load from the shock wave on buildings, structures and structural elements in which shelters are located.

Tabl. 4. Fig. 2. Ref. 12.

Автор (вчена ступень, вчене звання, посада): доктор технічних наук, професор кафедри оперативного та бойового забезпечення Національного університету оборони України імені Івана Черняховського, КОЦЮРУБА Володимир Іванович

Адреса робоча: 03049, м. Київ, Повітрофлотський пр., 28, Національний університет оборони України ім. Івана Черняховського.

Робочий тел.: +38 044 271-08-68, факс +38 044 271-06-97 03680

Мобільний тел.: +38(050) 833-31-90, 
E-mail: kotcuru@ukr.net

ORCID ID: http://orcid.org/0000-0001-6565-9576

Автор (вчена ступень, вчене звання, посада): кандидат технічних наук, докторант Національного університету оборони України імені Івана Черняховського, ДАЦЕНКО Іван Петрович

Адреса робоча: 03049 , м. Київ, Повітрофлотський проспект, 28, Національний університет оборони України імені Івана Черняховського

Робочий тел.: + 38044 271-08-68, факс +38 044 271-06-97 03680

Мобільний тел.: +38(093) 475-31-67

E-mail: docik_ivan@i.ua

ORCID ID: https://orcid.org/0000-0002-0047-413X

Автор (вчена ступень, вчене звання, посада): кандидат технічних наук, доцент, доцент кафедри технічного забезпечення Національного університету оборони України імені Івана Черняховського, ДАЧКОВСЬКИЙ Володимир Олександрович

Адреса робоча: 03049 , м. Київ, Повітрофлотський проспект, 28, Національний університет оборони України імені Івана Черняховського.

Робочий тел.: +38 044 271-06-97, факс +38 044 271-06-97 03680

Мобільний тел.: +38(067) 422-21-75,

E-mail: 1903vova@ukr.net

ORCID ID: http://orcid.org/0000-0003-1480-5021

Автор (вчена ступень, вчене звання, посада): ад'юнкт кафедри оперативного та бойового забезпечення Національного університету оборони України імені Івана Черняховського, ЧЕРЕВКО Руслан Михайлович

Адреса робоча: 03049 , м. Київ, Повітрофлотський проспект, 28, Національний університет оборони України імені Івана Черняховського

Робочий тел.: +38 044 271-08-68, факс +38 044 271-06-97 03680

Мобільний тел.: +38(067) 841-04-44

E-mail: cherepruslan2017@gmail.com

ORCID ID: http://orcid.org/0000-0003-0414-0695

Автор (вчена ступень, вчене звання, посада): старший викладач кафедри оперативного та бойового забезпечення Національного університету оборони України імені Івана Черняховського, ПОЛЮЛЯК Василь Миколайович

Адреса робоча: 03049, м. Київ, Повітрофлотський проспект, 28, Національний університет оборони України імені Івана Черняховського

Робочий тел.: +38 044 271-08-68, факс +38 044 271-06-97 03680

Мобільний тел.: +38(097) 933-93-24

E-mail: polulyak1978@gmail.com

ORCID ID: http://orcid.org/0000-0002-6536-5612

Автор (вчена ступень, вчене звання, посада): ад'юнкт кафедри оперативного та бойового забезпечення Національного університету оборони України імені Івана Черняховського, ІВАЩУК Олександр Анатолійович

Адреса робоча: 03049, м. Київ, Повітрофлотський проспект, 28, Національний університет оборони України імені Івана Черняховського

Робочий тел.: +38 044 271-08-68, факс +38 044 271-06-97 03680

Мобільний тел.: +38(097) 584-61-63

E-mail: sashik-ivashchuk84@ukr.net

ORCID ID: http://orcid.org/0000-0002-8189-6472

Автор (вчена ступень, вчене звання, посада): доктор історичних наук, доцент, начальник кафедри історії війн і воєнного мистецтва Національного університету оборони України імені Івана Черняховського, ФУРМАН Ігор Іванович

Адреса робоча:03049, м. Київ, Повітрофлотський проспект, 28, Національний університет оборони України імені Івана Черняховського.

Робочий тел.: +38 044 271-08-68, факс +38 044 271-06-97 03680

Мобільний тел.: +38(096) 364-62-26,

E-mail:fi.2005@ukr.net

ORCID ID: http://orcid.org/0000-0002-3594-5499 